\title{
Species of the Torquata Group of Mallomonas
}

\author{
By KATHARINE HARRIS \\ Department of Botany, University of Reading, Reading, Berkshire
}

(Accepted for publication I3 December 1969)

\begin{abstract}
SUMMARY
A new species of the torquata group of the genus Mallomonas is described by light and electron microscopes. A list is given of those members of the torquata group which have been published with illustrations obtained with the use of light and electron microscopes. A few of the torquata group which have been published only with light microscope illustrations are listed and discussed. It is considered that no clear decision about their nomenclature can be reached without an electron micrograph of the scales.
\end{abstract}

\section{OBSERVATIONS}

Mallomonas allantoides sp.nov. (Fig. 3 to 6 ; Pl. I, fig. I to 5 )

Holotype (Pl. I, fig. I)

Latin diagnosis. Cellula ferme valde elongata, evidente flectens, aliquando formam commutans in momenta temporis aliquantum. Flagellum breve. Squamae in factinones tres divisae: circa quinque squamae collaris, permultae squamae corporis et squamae postremae paucae. Squamae collaris erectes, triquetrae alliquanto procerae, latus sinistrum paulum concavum, latus dextrum convexum, cupola forte constituta, cuspidata, nonnumquam setam brevem ferens. Scutum signatum squamarum corporis simile, margo recurvata, lata in latere convexo et basi scuti, finem faciens prope basim lateris concavi, sed continuata ad cupolam appendice scuti. Squamae corporis rhomboidales, productae transverse, cupola invalida, margo recurvata, praesens in latera due cupolae opposita. Scutum ora crassa et superficie crassitudinibus reticulatis inscriptum, macula una quaeque in tres aut quattuor divise. Squamae postremae minores, squamae ultimae minimae, aliquae squamarum postremarum reticulo inscriptae. Squamae ultimae ferme spinas attenuatas ferentes, non scripta ferme. Cellula I 3 ad $47 \mu \mathrm{m}$. longa, 5 ad $9 \mu \mathrm{m}$. lata, squamae collaris et corporis $2.5 \times 4 \mu \mathrm{m}$. Cystum I 2 ad $\mathrm{I} 5 \mu \mathrm{m}$. in arta cellula materna. Setae 6 ad $8 \mu \mathrm{m}$. longa, spina 3 ad $9 \mu \mathrm{m}$. longa.

English diagnosis. Cell normally much elongated, distinctly flexible, sometimes changing its shape in minutes. Flagellum short. Scales comprising three groups: about five collar scales; numerous body scales; a few rear scales. Collar scales erect, triangular, rather long; left side slightly concave, right side convex, dome strongly developed, pointed, sometimes bearing short bristle. Shield marked as shields of body scales. Flange recurved, broad on convex side and base of shield, ending near base of concave side but joined to dome by appendage. Body scales rhomboidal, transversely elongated, dome feebly developed, flange recurved, developed on two sides opposite dome, shield with thickened edge and surface marked with reticulate thickenings, each mesh divided into three or four. Rear scales smaller, last scales smallest, some rear scales with 
reticulate marks. Last scales usually unmarked but bearing tapering spines. Cell $\mathrm{I} 3$ to $47 \mu \mathrm{m}$. long, 5 to $9 \mu \mathrm{m}$. wide, collar and body scales $2 \cdot 5 \times 4 \mu \mathrm{m}$. Cyst 12 to $15 \mu \mathrm{m}$. in diameter in close fitting mother cell. Bristles 6 to $8 \mu \mathrm{m}$. long, spines 3 to $9 \mu \mathrm{m}$. long.

Occurrence. The species is rare in the Reading district (Berkshire, England) and I have found it in only two localities. The type locality was a roadside pond now filled-in; the other pond was on gravel and surrounded by trees and rhododendrons. Both ponds are on what appeared to be poor land. The specific epithet allantoides means sausage-like, to suggest the organism's shape.
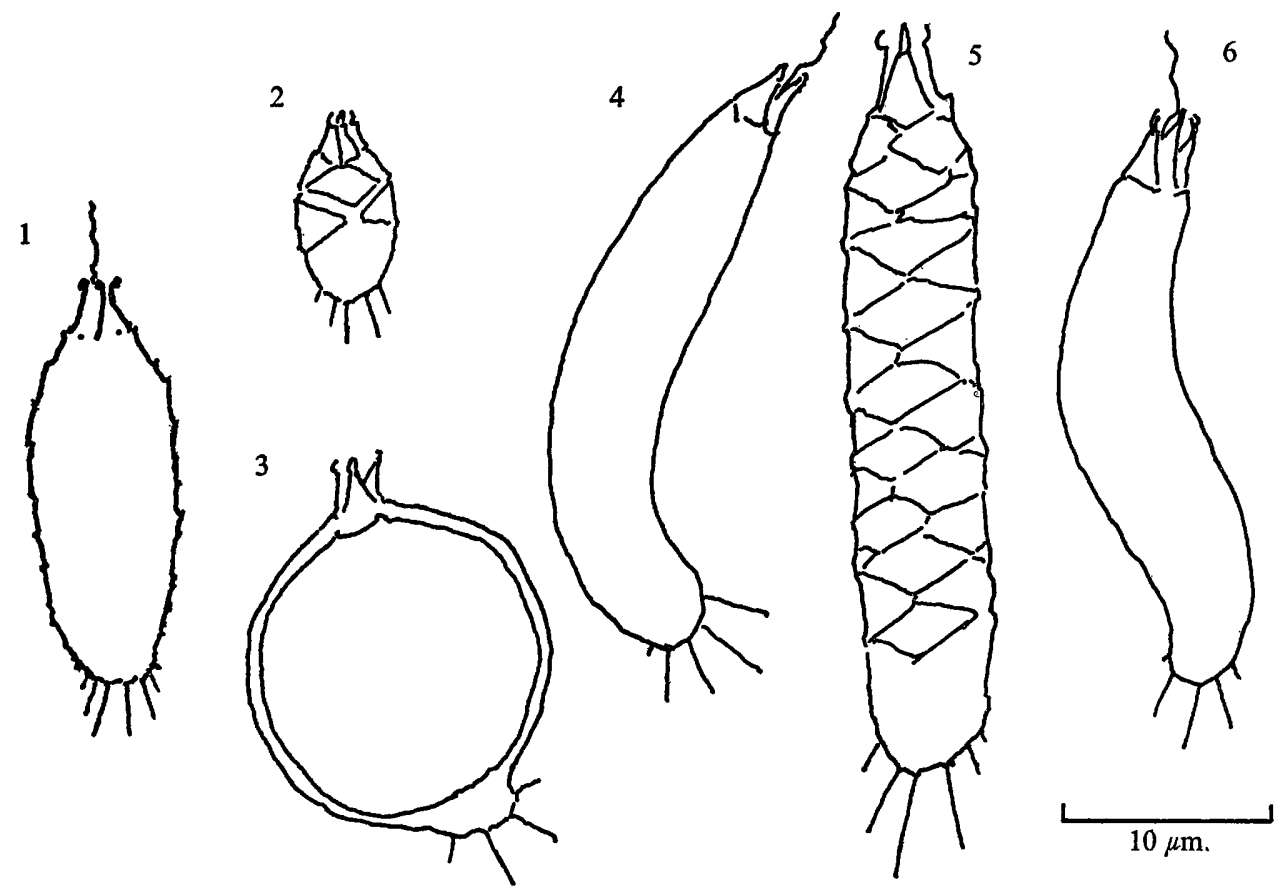

Fig. I to 6. I, Mallomonas doignonii perfect form. 2, $M$. doignonii, imperfect form. 3, $M$. allantoides, encysted. Fig. 4 to $6, M$. allantoides, perfect forms showing changes of shape.

\section{DISCUSSION}

Mallomonas allantoides is of interest in being the most flexible Mallomonas species that I have seen. It has a long slender cell which does not change much in width until it approaches encystment. Then the armour stretches until it is nearly spherical, enclosing a spherical cyst.

There are only two other species of the torquata group of the genus Mallomonas bearing spines which have been examined with both light and electron microscopes. These are M. doignonii Bourrelly, I95I ; Harris \& Bradley, I957; and M. eoa Takahashi, 1963. Of these species $M$. allantoides has the longest cell and its cell has unusual flexibility; $M$. eoa has the longest rear spines, while $M$. doignonii is much the same length as $M$. eoa but has much shorter spines; $M$. doignonii also has a marked rigidity in its armour which is difficult to break up, at least in its perfect form. The three species may be distinguished at once by the electron micrograph of the scales. The $M$. 
doignonii scale has thickened striations, usually vertical; $M$. allantoides scale gives the impression of having one network superimposed upon another which is less well marked; $M$. eoa has a single close network of circular holes. $M$. doignonii Bourrelly I95I is the same as that figured by Harris \& Bradley (I957) as M. coronata, Pl. I, fig. 7 , and discussed in Harris \& Bradley (1960).

An imperfect form of $M$. allantoides (Pl. I, fig. 2) has some well-developed rear spines, but as is usual in a dried specimen at this stage, the armour has collapsed and partly disintegrated. Fig. $\mathrm{I}$ is a perfect form of $M$. doignonii and Fig. 2 an imperfect form of it which although short and with fewer body scales has fully developed rear spines.

Species of the torquata group which have been studied with both light and electron microscope

Species with rear spines over I $\mu \mathrm{m}$. long:

M. doignonii Bourrelly I95I, Harris \& Bradley 1957, I960;

$M$. eoa Takahashi, I963; this includes $M$. clavus Bradley, I964;

$M$. allantoides, present paper.

Species without rear spines but often showing rear points less than I $\mu \mathrm{m}$. long:

M. pumilio var. schwemmlei Glenk, 1956; electron-microscope illustrations, Fott \& Ettl, 1959, see below;

M. pumilio Harris \& Bradley, 1957, 1960;

M. pumilio var. silvicola Harris \& Bradley, I960;

$M$. pumilio many unnamed varieties, this periodical;

$M$. phasma Harris \& Bradley, I960;

$M$. mangofera Harris \& Bradley, I960;

M. grata Takahashi, 1963 .

$M$. pumilio var. schwemmlei was first described with the light microscope by Glenk (I956) as Mallomonas schwemmlei. Its electron micrograph was then published, together with a good light micrograph showing its general habit, by Fott \& Ettl (I959). This was before it was fully realized that the rear point was a rigid part of the scale and not capable of change into a spine. I have therefore renamed it $M$. pumilio var. schwemmlei.

There are three species of Mallomonas of the torquata group with rear spines that have been described since 1940 but with the light microscope only. They all have a certain similarity, and bearing in mind the variation in shape which may occur in one species and the variation in interpretation of very small objects, I believe that an electron micrograph of the scale is the only way to compare them.

These three species are:

M. coronifera Matvienko, I94I. Ukrainian material;

$M$. lefeuvrier Villeret, 1954. French material;

M. coronifera Perman \& Vinnikova, 1955. Czech material.

There is a species with a small cell and no spines, $M$. potsdamiensis Bethge, I954. We have information with the light microscope only but it deserves electron microscope study. 


\section{REFERENCES}

BETHGE, H. (1954). 'Mallomonas potsdamensis'; eine neue Mallomonas Art. Bericht der deutschen botanischen Gesellschaft 67, 69 .

Bourrelly, P. (195I). Une nouvelle espèce de Chrysomonadine Mallomonas doignonii. Bulletin Société botanique de France $98,156$.

Bradery, D. E. (1964). A study of the Mallomonas, Synura and Chrysosphaerella of Northern Ireland. Journal of General Microbiology 37, 321.

FotT, B. \& ETrL, H. (1959). Das Phytoplankton der Talsperre bei Sedlice. Preslia 3r, 2 I 3.

GlenK, O. H. (1956). Mallomonas schwemmlei, eine neue Chrysomonade aus dem Plankton eines fränkischen Teiches. Bericht der deutschen botanischen Gesellschaft 69, 189.

HARRIS, K. \& BradLey, D. E. (1957). An examination of the scales and bristles of Mallomonas in the electron microscope using carbon replicas. Journal of the Royal Microscopical Society 76, 37.

HARRIS, K. \& BRADLEY, D. E. (1960). A taxonomic study of Mallomonas. Journal of General Microbiology 22, 750 .

Matvienko, O. M. (I94I). A contribution to the taxonomy of the genus Mallomonas. Proceedings of the Botanical Institute, Kharkov. 4, 4I.

Perman, J. \& Vinnikova, A. (1955). Three Chrysomads of winter plankton. Preslia $27,272$.

TAKAHASH, E. (1963). On two new species of Mallomonas found in ditches at Tsuruoka in the North East Japan. Bulletin of the Yamagata University (Agricultural Sciences) 4, 169.

VILleret, S. (1954). Deux nouvelles espèces Chrysomonadines 'Mallomonas minuta' et 'Mallomonas lefeuvrei'. Bulletin Société botanique de France 101, 106.

\section{EXPLANATION OF PLATE}

Mallomonas allantoides

Fig. I. Whole perfect cell. $\times 4000$. Direct electron micrograph.

Fig. 2. Whole imperfect cell. $\times 4000$. Replica.

Fig. 3. Collar scale. $\times$ I0,000.

Fig. 4. Body scale. $\times$ I0,000.

Fig. 5. Rear scales, two with spines. $\times$ I0,000. 
Journal of General Microbiology, Vol. 6I, No. I

Plate I
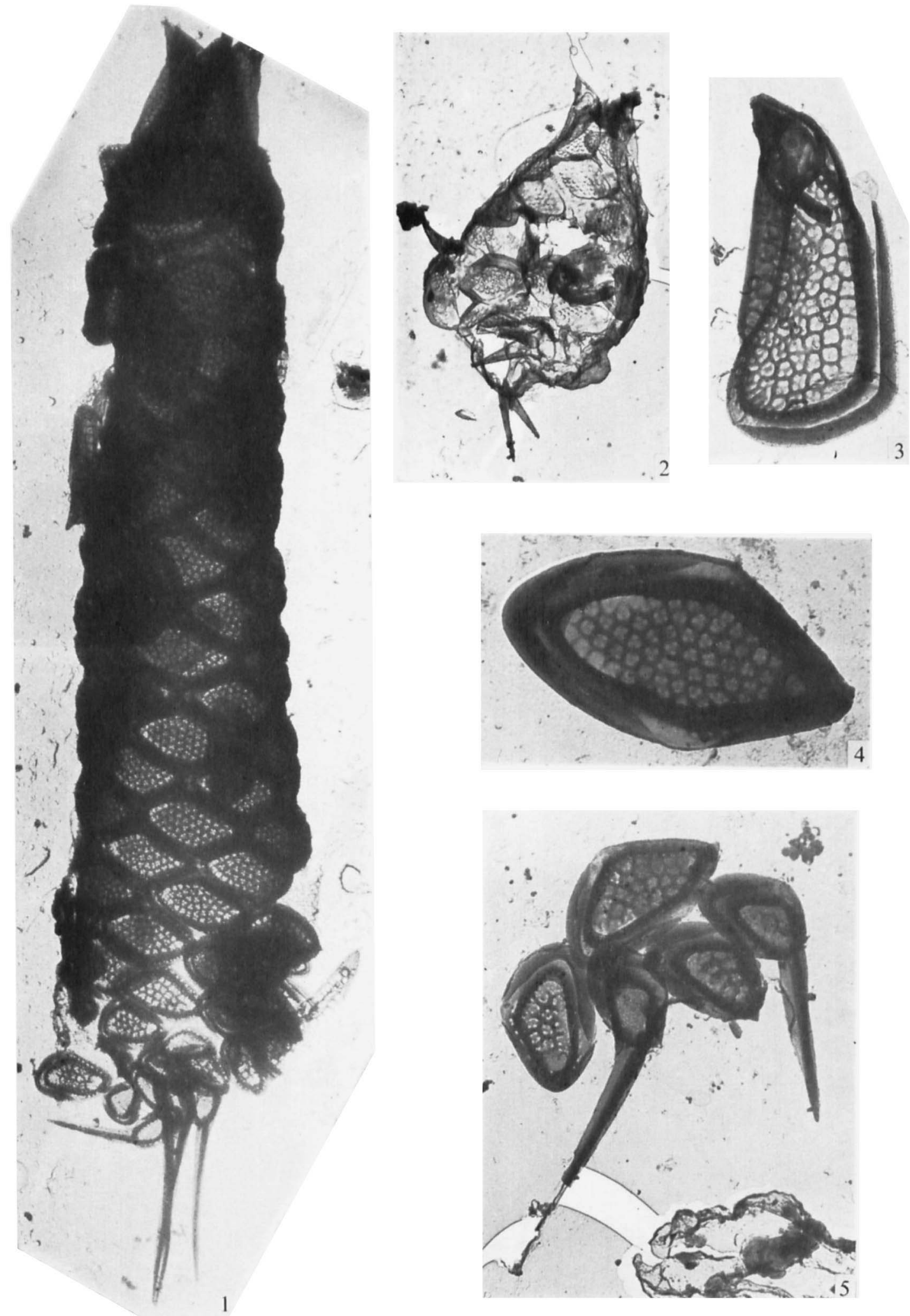

K. HARRIS

(Facing p. 80) 